\title{
Binding of human, porcine and bovine insulin to insulin receptors from human brain, muscle and adipocytes and to expressed recombinant alternatively spliced insulin receptor isoforms
}

\author{
G. Kotzke ${ }^{1}$, M. Schütt ${ }^{1}$, U. Missler ${ }^{2}$, D. E. Moller $^{3}$, H. L. Fehm ${ }^{1}$, H.H. Klein ${ }^{1}$ \\ ${ }^{1}$ Department of Internal Medicine, University of Lübeck, Lübeck, Germany \\ ${ }^{2}$ Department of Neurosurgery, University of Lübeck, Lübeck, Germany \\ ${ }^{3}$ Department of Medicine, Beth Israel Hospital and Harvard Medical School, Boston, Massachusetts, USA
}

\begin{abstract}
Summary Previous studies have suggested that human and porcine insulin exert identical effects on blood glucose and counter-regulatory hormones but elicit different neurophysiological reactions. A major goal of the present study was to investigate whether this could be caused by different relative affinities of the insulins from different species to insulin receptors from the brain compared to other tissues. Insulin receptors isolated from human brain, muscle or adipocytes as well as from cultured cells over-expressing either of the human insulin receptor isoforms (exon $11-$ or exon $11+$ ) were immobilized to microwells coated with monoclonal anti-insulin receptor antibody. Subsequently the binding of human, porcine and bovine insulin was measured. While the receptors derived from the different tissues had different affinities for insulin, there were no tissue-specific dif-
\end{abstract}

ferences in the relative binding of the insulins of the three species. The insulins of the three species were also not different with regard to their binding to the receptor isoforms. Finally, in human brain homogenates no differences in the degradation rates for human, porcine and bovine insulin were detected. Thus, our data do not support the hypothesis that different neurophysiological reactions during hypoglycaemia due to human or porcine insulin are caused by differences of the binding of the insulins to human brain insulin receptors or their degradation in the human brain. [Diabetologia (1995) 38: 757-763]

Key words Human insulin, porcine insulin, brain, insulin receptor, insulin degradation
There has been controversy concerning whether treatment with human insulin may result in a reduced hypoglycaemia awareness, compared with treatment with porcine insulin [1-9]. The question of whether hypoglycaemia unawareness could be different depending on whether human or porcine insulin was used and if this was the result of a different influence of the insulins on neurophysiological function has been addressed by Kern et al. [10-12].

Received: 18 July 1994 and in revised form: 6 December 1994

Corresponding author: Dr. H. H. Klein, Klinik für Innere Medizin, Medizinische Universität zu Lübeck, Ratzeburger Allee 160, D-23538 Lübeck, Germany

Abbreviations: BSA, Bovine serum albumin; SDS, sodium dodecyl sulphate; AEP, auditory-evoked potentials; VEP, visualevoked potentials.
They recorded auditory-evoked potentials (AEP) and visual-evoked potentials (VEP) during human and porcine insulin-induced hypoglycaemia and found that porcine insulin elicited stronger effects on AEP $[10,11]$ and VEP [12] components than human insulin. Insulin receptors are widely distributed in the human brain $[13,14]$ and insulin in the brain has been shown to be plasma-derived [15-17]. One potential reason for a different action of human and porcine insulin in the brain was thought to be that the insulins derived from the different species have different relative affinities for the insulin receptors in the brain compared to receptors in other tissues.

The human insulin receptor mRNA is transcribed from a single gene located on human chromosome $19[18,19]$. This, however, does not exclude differences in the binding characteristics of insulin receptors 
in different tissues. Firstly, alternative splicing of a small cassette exon (exon 11) of the receptor gene results in two transcripts that are expressed in a tissue-specific manner and have different binding properties [19-22]. Secondly, animal studies suggest that structural and functional differences of the insulin receptors from different tissues of the same species exist due to post-translational modification of the receptors [23-25]. In the present study we have therefore systematically evaluated the binding of human, porcine and bovine insulin to human insulin receptors derived from brain, muscle and fat tissue as well as from cultured cells over-expressing either of the two alternatively spliced receptor isoforms (exon 11 - or A-isoform and exon $11+$ or B-isoform).

Another possible explanation for different effects of the insulins of the three species in the brain could involve differential rates of their degradation in this tissue. There appears to be a rate-limited insulin transport capacity across the blood-brain barrier [15-17] and thus different degradation rates could potentially result in different effective concentrations of the insulins in the brain despite similar plasma concentrations. To investigate this possibility, we measured the degradation rates of the insulins of the three species in homogenates of brain tissue.

\section{Materials and methods}

HPLC-purified unlabelled insulins and [ ${ }^{125}\left[-T y r-A^{14}\right]$-monoiodoinsulins $(2200 \mathrm{Ci} / \mathrm{mol})$ were kindly provided by $\mathrm{Dr}$. G. Seipke (Hoechst AG, Frankfurt, Germany). Disuccinimidyl suberate was purchased from Pierce (Rockford, Ill., USA). Materials for sodium dodecyl sulphate-polyacrylamide gel electrophoresis (SDS-PAGE) were from Bio-Rad (Munich, Germany). Mouse hybridoma cells producing a monoclonal anti-insulin receptor antibody ( $\alpha I R 1$-antibody [26] were from American Type Culture Collection (Rockville, Ill., USA). Goat anti-mouse IgG was from Dianova (Hamburg, Germany) and 96-well polystyrene plates were from Dunn (Ansbach, Germany).

Solubilization of the tissues. Human tissues were obtained in accordance with the principles of the Declaration of Helsinki. All tissue used in this study needed to be removed for therapeutic reasons and was not required for diagnostic (e.g. evaluation by a pathologist) procedures. Brain samples (temporal or frontal cortex) were derived from tissue that needed to be removed in the course of neurosurgery. Parts of the tissue that were identified morphologically as healthy brain tissue $(0.2-$ $0.9 \mathrm{~g}$ ) were used for the isolation of insulin receptors. Human skeletal muscle and subcutaneous adipose tissue came from leg amputations and surgery for breast reduction, respectively. Cell extracts that contained the insulin receptor isoforms were prepared from Chinese hamster ovary cell lines over-expressing the isoforms that were prepared as previously described [27]. Adipose, muscle and brain tissue were processed within $60 \mathrm{~min}$ after surgery. Adipocytes were isolated from minced adipose tissue in collagenase containing buffer [final concentrations: $1.2 \mathrm{mg} / \mathrm{ml}$ collagenase, (in mmol/1) $130 \mathrm{NaCl}, 4.83$
$\mathrm{KCl}, 1.20 \mathrm{KH}_{2} \mathrm{PO}_{4}, 1.30 \mathrm{MgSO}_{4}, 1.20 \mathrm{CaCl}_{2}, 40 \mathrm{Hepes}, 3 \mathrm{glu}-$ cose, $4 \%$ bovine serum albumin (BSA)]. Subsequently the adipocytes were washed to remove the collagenase and solubilized by shaking with ice cold solubilization buffer (final concentrations: $1 \%$ Triton $X 100,2.5 \mathrm{mmol} / \mathrm{l}$ phenylmethyl-sulfonylfluoride, 800 trypsin inhibitor $\mathrm{U} / \mathrm{ml}$ aprotinin, $2.3 \mathrm{mmol} / \mathrm{l}$ bacitracine, $6.67 \mathrm{mmol} / \mathrm{l}$ benzamidine, $2.5 \mu \mathrm{g} / \mathrm{ml}$ leupeptin, $2.5 \mu \mathrm{g} / \mathrm{ml}$ pepstatin). The pieces of muscle and brain tissue were directly homogenized and solubilized in the buffer as for adipocytes using a motor-driven Elvehjem homogenizer. After $20 \mathrm{~min}$ at $4^{\circ} \mathrm{C}$, the samples were centrifuged at $10^{5} \mathrm{~g}$ to remove insoluble material and then stored at $-80^{\circ} \mathrm{C}$ until assayed. Protein in the solubilized tissue preparations was measured by a modification of the method of Lowry [28] using BSA standards (Bio-Rad DC-assay).

Immobilization of insulin receptors. Microwells were prepared as previously described [29] by first coating the bottom of the wells with goat anti-mouse IgG followed by an incubation with aIR1-containing hybridoma supernatant (serum-free). To immobilize the receptors, $30 \mu \mathrm{l}$ of the tissue extracts was then pipetted into the microwells where $\alpha$ IR1-antibody had been attached. After an incubation for $16 \mathrm{~h}$ at $4^{\circ} \mathrm{C}$ the supernatants were removed and the wells washed five times with buffer that contained $0.5 \%$ Triton X $100,100 \mathrm{mmol} / 1 \mathrm{NaCl}$, $2.5 \mathrm{mmol} / \mathrm{l} \mathrm{KCl}, 1 \mathrm{mmol} / 1 \mathrm{CaCl}_{2}, 20 \mathrm{mmol} / \mathrm{l} \mathrm{Hepes}, 10 \% \mathrm{gly}-$ cerol, $0.5 \%$ azide, and $0.5 \% \mathrm{BSA}, \mathrm{pH} 7.4$ (referred to as "binding buffer").

Affinity cross-linking. Cross-linking between ${ }^{125}$ I-insulin and the insulin receptors was carried out as described by Pilch and Czech [30] with minor modifications. The microwells with the immobilized receptors were first incubated for $16 \mathrm{~h}$ at $4^{\circ} \mathrm{C}$ with $30 \mu \mathrm{l} 5 \mathrm{nmol} / \mathrm{l}{ }^{125}$ I-insulin in binding buffer in the presence or absence of $3.3 \mu \mathrm{mol} / \mathrm{l}$ unlabelled insulin. Unbound insulin was removed by two washes with phosphate buffer [(in $\mathrm{mmol} / 1) 128 \mathrm{NaCl} ; 5.2 \mathrm{KCl} ; 0.65 \mathrm{CaCl}_{2} ; 1.29 \mathrm{KH}_{2} \mathrm{PO}_{4} ; 1.0$ $\mathrm{Na}_{2} \mathrm{HPO}_{4}$ ). The cross-linker disuccinimidyl suberate (final concentration: $0.5 \mathrm{mmol} / \mathrm{l}$ ) was then added. After $15 \mathrm{~min}$ the reaction was quenched by the addition of $50 \mu$ Laemmli buffer [31] for $30 \mathrm{~min}$ at room temperature. The proteins were separated by SDS-PAGE electrophoresis and visualized by autoradiography $[32,33]$.

Insulin binding. The immobilized receptors (5-10 fmol insulin binding capacity) were incubated in $100 \mu \mathrm{l}$ binding buffer with $16.7 \mathrm{pmol} / 125 \mathrm{I}$-labelled human insulin and increasing concentrations of unlabelled human, porcine or bovine insulin for $16 \mathrm{~h}$ at $4^{\circ} \mathrm{C}$. Unbound insulin was removed by five washes with binding buffer. ${ }^{125}$ I-insulin that had bound to the immobilized receptors was collected by twice adding a solution of $2 \%$ SDS to the wells (30 $\mathrm{min}$ at room temperature). The radioactivity in the collected SDS-solution was determined by gamma-counting. Equilibrium association constants $(\mathrm{Ka})$ for the binding of the insulins of the three species to the insulin receptors were calculated using the one-site model of the program "LIGAND" [34].

Insulin degradation. Brain tissue was homogenized in an icecold buffer [(in mmol/1) $130 \mathrm{NaCl}, 4.83 \mathrm{KCl}, 1.20 \mathrm{KH}_{2} \mathrm{PO}_{4}$, $1.30 \mathrm{MgSO}_{4}, 1.20 \mathrm{CaCl}_{2}, 20 \mathrm{Hepes}, 1 \% \mathrm{BSA}$ ] using a motordriven potter homogenizer. The homogenized tissue was incubated at room temperature with a final concentration of 0.26 $\mathrm{nmol} / 1{ }^{125}$ I-labelled human, bovine or porcine insulin. At defined times ice-cold trichloroacetic acid (final concentration $30 \%$ ) was added and the samples centrifuged. The precipitated radioactivity was considered as non-degraded insulin. 


\section{Results}

Affinity cross-linking ${ }^{125}$ I-insulin affinity cross-linking was performed to compare the apparent molecular weights of the insulin receptors from different tissues. Figure 1 shows that the apparent molecular weights of the $\alpha$-subunits of insulin receptors from muscle or adipose tissue were $125 \mathrm{kDa}$, whereas the apparent molecular weight of the $\alpha$-subunits of brain insulin receptors was $115 \mathrm{kDa}$. Cross-linking in the presence of unlabelled insulin revealed no visible radioactive bands demonstrating the specificity of the ${ }^{125}$ I-insulin binding (Fig. 1).

Insulin binding. Competition curves for the binding of human, porcine and bovine insulin to the receptors from brain, muscle or fat tissue as well as from CHO-cells over-expressing the A- or B-insulin receptor isoform are shown in the Figure 2 . The competition curves of the different insulins with human ${ }^{125} \mathrm{I}$ insulin are almost superimposable and in none of the different insulin receptors tested was there a significant difference between human, porcine and bovine insulin in their ability to compete with ${ }^{125}$ I-labelled human insulin. This is also confirmed by the calculation of the equilibrium association constants $(\mathrm{Ka})$ in Table 1. While there were no detectable differences between the binding properties of the insulins from the different species, the data in Figure 2 and Table 1 reveal differential insulin binding properties of the receptors derived from the different tissues. From the human tissues tested, brain receptors had the highest, and receptors from adipocytes the lowest affinity for insulin. From the expressed recombinant insulin receptor isoforms, the A-form displayed the higher affinity.

Insulin binding capacities estimated by the program "LIGAND" (two-site model and assuming that the capacities were similar with the insulins of the different species) for brain, muscle and adipocytes, respectively, were $6.6 \pm 1.1,6.5 \pm 2.1$ and $9.3 \pm 1.3 \mathrm{fmol}$ per well or $24 \pm 5,17 \pm 5$ and $19 \pm 3$ fmol per mg protein of the solubilized tissue samples that had been added to the wells.

Insulin degradation studies. Figure 3 shows that there were no detectable differences between the degradation rates of human, porcine or bovine insulin in brain homogenate.

\section{Discussion}

While a large number of previous studies that compared human and porcine insulin have demonstrated similar biologic potencies in humans and similar insulin receptor binding characteristics in a variety of human and animal tissues $[35,36]$, there were some indi-

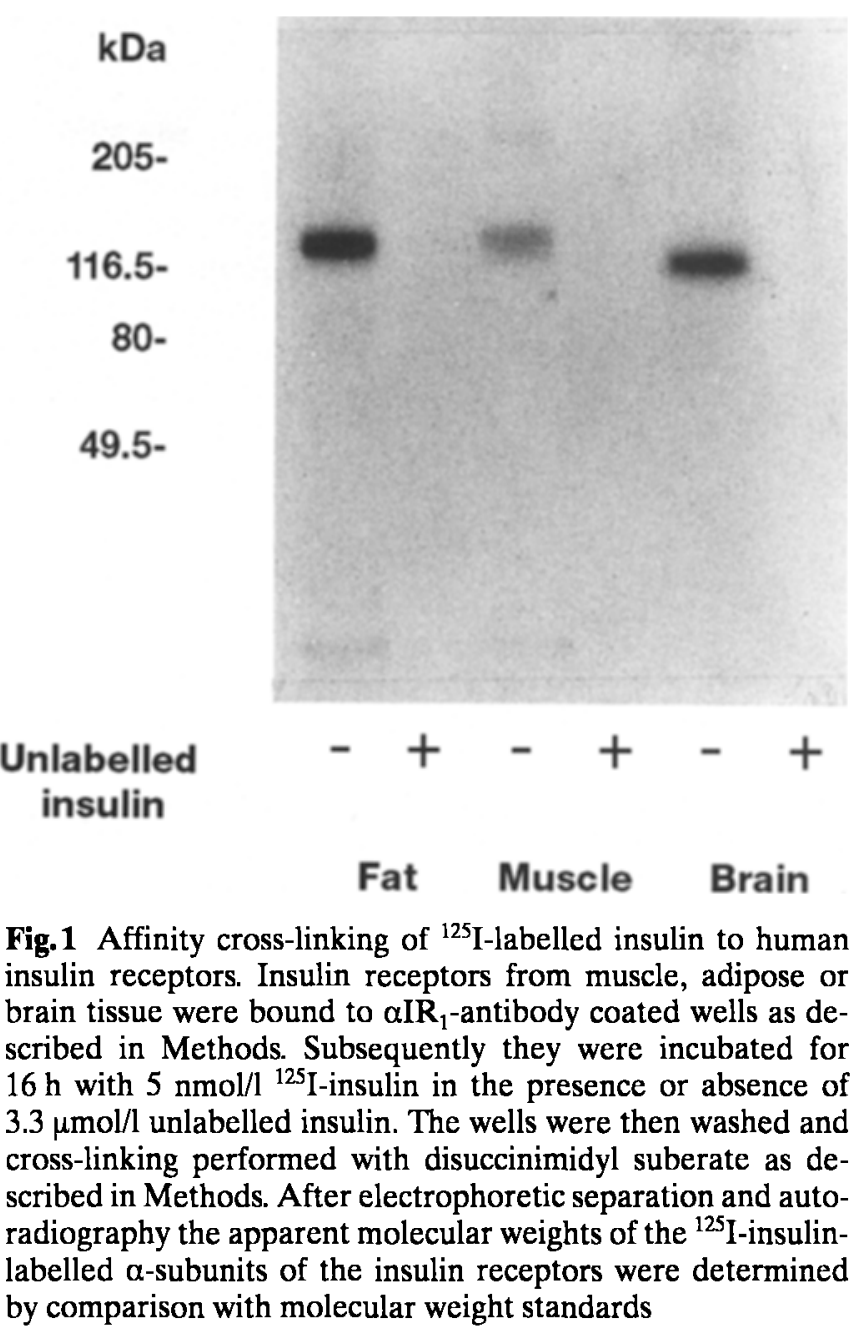

Table 1. Insulins of different species and their binding properties to receptors from different tissues

\begin{tabular}{llll}
\hline & Human insulin & Porcine insulin & Bovine insulin \\
\hline Brain & $5.98 \pm 1.14$ & $6.48 \pm 1.89$ & $6.47 \pm 1.68$ \\
Muscle & $3.54 \pm 1.31$ & $4.77 \pm 1.27$ & $3.93 \pm 0.98$ \\
Adipocyte & $2.52 \pm 0.23$ & $2.27 \pm 0.38$ & $2.32 \pm 0.53$ \\
A-isoform & $8.46 \pm 1.09$ & $9.16 \pm 1.28$ & $9.62 \pm 1.44$ \\
B-isoform & $4.59 \pm 0.64$ & $5.47 \pm 0.65$ & $5.73 \pm 0.68$ \\
\hline
\end{tabular}

Equilibrium association constants (Ka; in $1 / \mathrm{mol} \cdot 10^{9} \pm \mathrm{SEM}$ ) for human, porcine and bovine insulin receptors from brain, muscle and adipose tissue as well as to expressed recombinant A- and B-insulin receptor isoforms. The data of the competition curves of three independent experiments were analysed by the program LIGAND [34] using the one-site model

cations that this could be different in the brain. Recent reports have demonstrated differential effects of human and porcine insulin-induced hypoglycaemia on neurophysiological reactions in human subjects [10-12] and thus suggested that these insulins might act differently in the human brain. Other studies have shown that the brain insulin receptor has unique structural and functional properties $[16,23$, 

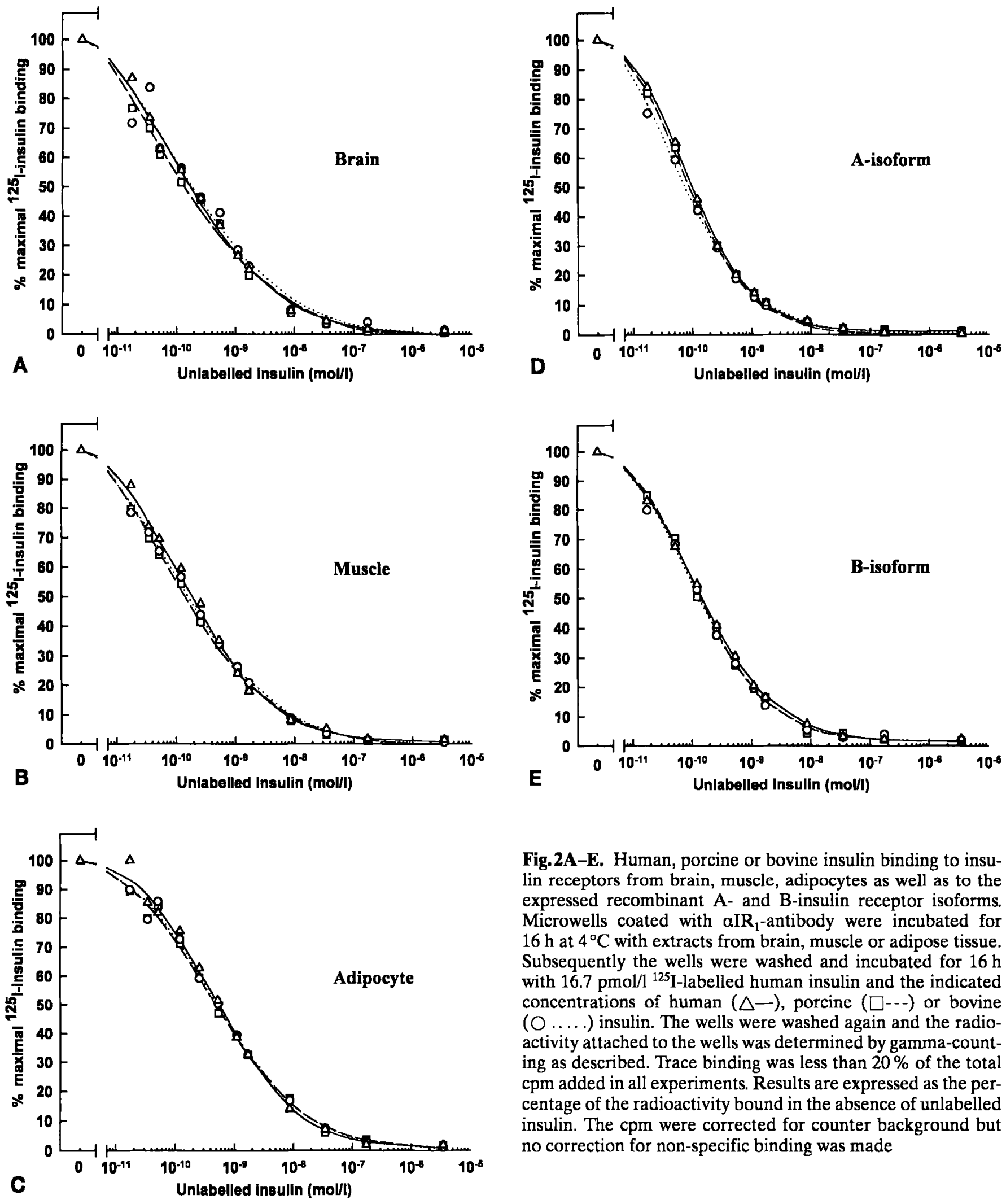

Fig.2A-E. Human, porcine or bovine insulin binding to insulin receptors from brain, muscle, adipocytes as well as to the expressed recombinant A- and B-insulin receptor isoforms. Microwells coated with $\alpha \mathrm{IR}_{1}$-antibody were incubated for $16 \mathrm{~h}$ at $4^{\circ} \mathrm{C}$ with extracts from brain, muscle or adipose tissue. Subsequently the wells were washed and incubated for $16 \mathrm{~h}$ with $16.7 \mathrm{pmol} / \mathrm{l}^{125}$ I-labelled human insulin and the indicated concentrations of human $(\Delta-)$, porcine $(\square--)$ or bovine $(\mathrm{O} \ldots .$.$) insulin. The wells were washed again and the radio-$ activity attached to the wells was determined by gamma-counting as described. Trace binding was less than $20 \%$ of the total cpm added in all experiments. Results are expressed as the percentage of the radioactivity bound in the absence of unlabelled insulin. The cpm were corrected for counter background but no correction for non-specific binding was made

37] and in fact, Schlüter et al. [38] reported a lower binding affinity of human insulin compared to porcine insulin to pig brain cells but not to pig liver. In contrast, Gammeltoft et al. [39] who investigated rat brain cortex synaptosomes did not find such a difference between human and porcine insulin; he found,

however, that the relative affinities between porcine insulin, porcine proinsulin and coypu insulin differ between the synaptosomes and rat liver cells.

The major question of the present study was therefore whether human brain insulin receptors differ from the receptors in other human target tissues 


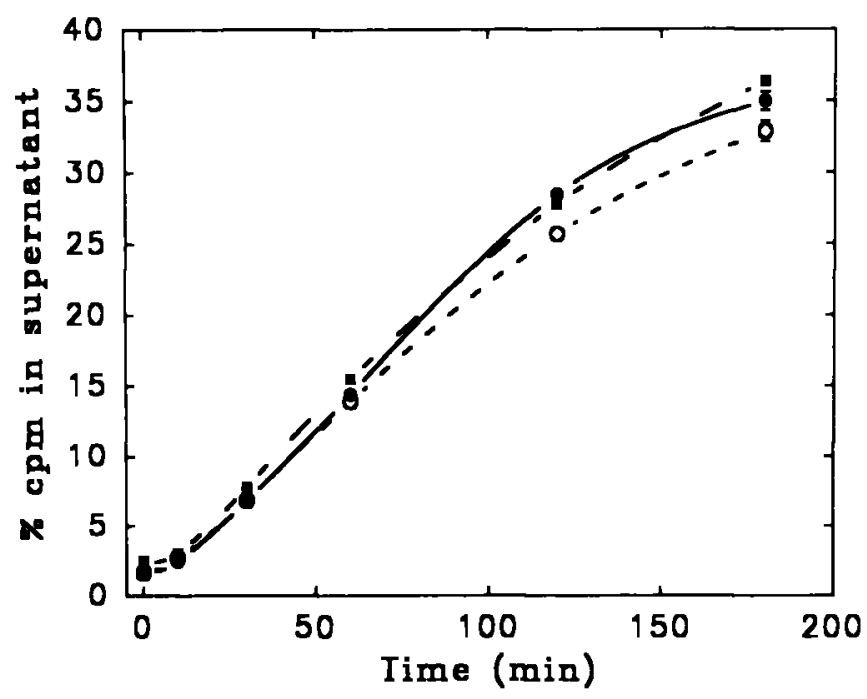

Fig. 3 Insulin degradation in brain tissue homogenate. Homogenates from brain tissue were incubated with $0.26 \mathrm{nmol} / \mathrm{l}^{125} \mathrm{I}$ labelled human (๑), porcine $(\boldsymbol{\square})$ or bovine $(0)$ insulin at room temperature. At the indicated times the non-degraded insulin was precipitated with ice cold $30 \%$ trichloroacetic acid. After centrifugation the radioactivity in the precipitates and the supernatants was determined by gamma-counting. The figure shows the cpm measured in the supernatants as a percentage of the total cpm

with respect to their properties of binding human, porcine and bovine insulin. The advantages of a previously described microwell-based insulin binding assay [29] were utilized to directly compare the binding properties of the insulins of the three different species to insulin receptors from human brain, human muscle and human adipocytes. The immobilized receptors were essentially pure and thus there was almost no non-specific binding and a very low insulin degradation rate (less than $1 \%$ ). Furthermore, assays with all three insulins and all tissues could be performed in parallel which allowed direct comparisons. Finally, small amounts of tissue were sufficient which was particularly important for studying the human brain.

Our data show that there were no tissue-specific differences in the relative binding of human, porcine or bovine insulin to the receptors of any given tissue, including brain tissue. The minute tendency to the right of the mean competition curves for human compared to porcine insulin (Fig. 2) was not present in all experiments and was not statistically significant. It may reflect a slightly incorrect standard insulin concentration in one experiment and should not be taken as an indication for differential binding properties of the different insulins. In any case, this minute and statistically insignificant tendency was not specific for the brain insulin receptors and was also seen in the receptors of the other tissues. Our results therefore do not support the hypothesis that human brain insulin receptors, as compared with the receptors of other human tissues, possess specific properties that would result in a differential binding of the insulins of the three species and that could explain the observed differences in neurophysiological reactions [10-12]. To be certain that the receptors derived from the brain samples were typical brain insulin receptors, their typical reduced apparent molecular weight [23], as compared to the receptors from adipocytes or muscle, was demonstrated by insulin-affinity cross-linking (Fig. 1).

Our data conflict to some extent with the results of Schlüter et al. [38] who showed a reduced affinity of human insulin to the cells of the pig brain. While unquestionably the fact that in their study the brain tissue was derived from pigs and not humans, as in our study, could completely account for the discrepancies, there may be other explanations. Schlüter et al. incubated whole brain cells with insulin while we performed the binding experiments with purified insulin receptor. The possibility that factors other than the insulin receptors themselves contributed to a differential binding affinity of human and porcine insulin in the brain cell preparations (e.g. membrane properties) cannot be ruled out completely. On the other hand, Gammeltoft et al. [39] who measured the binding to rat brain synaptosomes, consistent with our results, found no differences between human and porcine insulin binding. Finally, it is not clear whether the labelled porcine and human insulins used in the study by Schlüter et al. [38] that had been obtained from different sources were comparable with respect to affinity, purity and concentration. At the time the study was performed, HPLC-purification of [ ${ }^{125} \mathrm{I}-\mathrm{Ty}$ $\mathrm{A}^{14}$ ]-monoiodoinsulins may still have been problematic [40].

We also investigated whether human, porcine and bovine insulin bind differently to the A- or B-isoforms of insulin receptors. Our data show that the insulins derived from each of the three species bind with a higher affinity to A-receptors than to B-receptors. This finding has been previously reported using insulin from a single species [20, 22, 27]. Despite these differences of the receptors, there were no differences between the binding of human, porcine and bovine insulin to a single receptor isoform. Thus, there was also no indication that a tissue-specific distribution of A- and B-receptors could cause a different relative binding of the insulins of the three species.

Another possible explanation for the observed differences in neurophysiological reactions [10-12] could be that the entry of the different insulins into the brain and/or their degradation in the brain were different. Such mechanisms could lead to different equilibrium insulin concentrations within the brain despite similar plasma insulin concentrations. There appears to be a rate-limited insulin receptor-mediated transport of insulin across the blood-brain barrier; this does not however exclude that other factors such as diffusion as a means of delivering insulin to 
the brain or certain brain areas also play an important role $[16,17]$. In the present study we used human brain homogenates to investigate the possibility of a different degradation of the insulins in brain and found no differences between the insulins of the three species. Our results therefore suggest that other mechanisms, e.g., potentially different diffusion characteristics into the brain or within the brain may be responsible for the observed differences in neurophysiological reactions. To that end, slight differences in the lipophilicity of the insulins $[35,36]$ may play a role.

While we failed to find differences between the insulins with regard to their binding properties, differences were observed in the affinity for insulin of the insulin receptors from the different tissues. Thus, we found a higher affinity towards insulin with receptors derived from brain compared to adipocyte insulin receptors. These differences in insulin-affinity of the receptors from different human tissues may lead to differential effects of certain insulin concentrations on the various target tissues and thus may be physiologically important. The binding studies were performed with receptors that were essentially pure after their immobilization to anti-insulin receptor antibody. The differences in insulin binding affinity of the receptors therefore cannot be explained by differences in the cellular environment but must be due to different properties of the purified receptors themselves. While a different abundance of A- and B-receptor isoforms in the tissues may have contributed to the differences in insulin binding affinity of the receptors from these tissues, this appears not to be the only mechanism. Thus, the affinity of receptors derived from adipocytes was even lower than that displayed by the expressed recombinant receptor isoform with the lower affinity (B-receptor isoform). Other mechanisms may include differential posttranslational modifications of the receptors in the different tissues [23-25, 41].

In conclusion we found that insulin receptors from different human tissues differ in their properties to bind insulin. There were however no detectable differences in the relative binding of human, porcine and bovine insulin to insulin receptors derived from human brain and other human tissues. Moreover, we have no indication that the degradation of the insulins of the three species is different in brain. Our data therefore do not support the hypothesis that differential interactions with the brain insulin receptor or differential degradation rates of human, porcine and bovine insulin in the brain contribute to the observed differences in neurophysiological reactions [10-12] or an altered hypoglycaemia awareness.

Acknowledgements. This work was supported by grants from Deutsche Forschungsgemeinschaft (KL 503/7-2 to H.H.K.). G.K. was supported by a postdoctoral fellowship grant by
Werner and Gertrud Müller Stiftung (TS 134/02/91). We thank Prof. G. M. Lösch, Department of Plastic Surgery, Medical University Lübeck, and Prof. Dr. H.-P. Bruch, Department of Surgery, Medical University Lübeck, for their cooperation in obtaining the human tissues. The morphological evaluation of the brain tissue by Dr. E. Reusche, Department of Pathology, Medical University of Lübeck is gratefully acknowledged. We thank Ms. M. Drenckhan for excellent technical assistance.

\section{References}

1. Perez-Fernandez R, Casanueva FF, Devesa J, Cabezas-Cerrato J (1985) Metabolic and hormonal parameters after insulin-induced hypoglycaemia in man, comparison between biosynthetic human insulin and purified pork insulin. Horm Metab Res 17: 351-354

2. Berger WG, Althaus BU (1987) Reduced awareness of hypoglycaemia after changing from porcine to human insulin in NIDDM. Diabetes Care 10: 260

3. Teuscher A, Berger WG (1987) Hypoglycaemia unawareness in diabetics transferred from beef/porcine insulin to human insulin. Lancet 15: 382-385

4. Berger W, Honegger B, Keller U, Jäggi E (1989) Warning symptoms of hypoglycaemia during treatment with human and porcine insulin in diabetes mellitus. Lancet 13: 10401044

5. Berger M (1987) Human insulin: much ado about hypoglycaemia (un) awareness. Diabetologia 30: 829-833

6. Jakober B, Lingenfelser T, Gluck H, Maassen T, Overkamp D, Renn W, Eggstein M (1990) Symptoms of hyperglycemia - a comparison between porcine and human insulin. Klin Wochenschr 68: 447-453

7. Wolff SP (1992) Trying times for human insulin. Nature 356: $375-376$

8. Colagiuri-S, Miller JJ, Petosz P (1992) Double-blind crossover comparison of human and porcine insulins in patients reporting lack of hypoglycaemia unawareness. Lancet 339 : 1432-1435

9. Maran A, Lomas J, Archibald H, Macdonald IA, Gale EA, Amiel SA (1993) Double blind clinical and laboratory study of hypoglycaemia unawareness after transferring to human insulin. BMJ 306: 167-171

10. Kern W, Lieb K, Kerner W, Born J, Fehm HL (1990) Different effects of human and pork insulin-induced hypoglycaemia on neuronal functions in humans. Diabetes 39: 10911098

11. Kern W, Kerner W, Pietrowsky R, Fehm HL, Born J (1994) Effects of insulin and hypoglycaemia on the auditory brain stem response in humans. J Neurophysiol 72: 678-683

12. Kern W, Schlosser C, Kerner W, Pietrowsky R, Born J, Fehm HL (1994) Evidence for effects of insulin on sensory processing in humans. Diabetes 43 : $351-356$

13. Havrankova J, Roth J, Braunstein M (1978) Insulin receptors are widely distributed in the central nervous system of the rat. Nature 272: 827-829

14. Pacold ST, Blackard WG (1979) Central nervous system insulin receptors in normal and diabetic rats. Endocrinology 105: 1452-1457

15. Unger JW, Livingston JN, Moss AM (1991) Insulin receptors in the central nervous system: localization, signaling mechanisms and functional aspects. Prog Neurobiol 36: 343-362

16. Schwartz MW, Figlewitz DP, Baskin S, Woods SC, Porte D (1992) Insulin in the brain: a hormonal regulator of energy balance. Endocr Rev 13: 387-414 
17. Wozniak, M, Rydzewski B, Baker SP, Raizada MK (1993) The cellular and physiological actions of insulin in the central nervous system. Neurochem Int 22: 1-10

18. Yang-Feng TL, Francke U, Ullrich A (1985) Gene for human insulin receptor: localization to a site on chromosome 19 involved in pre-B-cell leukemia. Science 239: 487-494

19. Moller DE, Yokota A, Caro JF, Flier JS (1989) Tissue-specific expression of two alternatively spliced insulin receptor mRNA's in man. Mol Cell Endocrinol 3: 1263-1269

20. Mosthaf L, Grako K, Dull TJ, Coussens L, Ullrich A, McClain DA (1990) Functionally distinct insulin receptors generated by tissue-specific alternative splicing. Eur Mol Biol Organ J 9: 2409-2413

21. Benecke H, Flier JS, Moller DE (1992) Alternatively spliced variants of the insulin receptor protein. Expression in normal and diabetic human tissues. J Clin Invest 89: 2066-2070

22. Yamaguchi Y, Flier JS, Benecke H, Ransil B, Moller DE (1993) Ligand binding properties of the two isoforms of the human insulin receptor. Endocrinology 3: 1132-1138

23. Heidenreich KA, Brandenburg D (1986) Oligosaccharide heterogeneity of insulin receptors in adipocytes and brain. Endocrinology 118: 1835-1842

24. Burant CF, Teutelar MK, Block NE, Buse MG (1986) Structural differences between liver and muscle derived insulin receptors in rats. J Biol Chem 261: 14361-14366

25. Brillon DE, Henry RR, Klein HH, Olefsky JM, Freidenberg GR (1988) Functional and structural differences in human and rat-derived insulin receptors: characterization of the $\beta$-subunit kinase activity. Endocrinology 123: 1837-1847

26. Kull FC, Jacobs S, Su Y, Svoboda ME, Van Wyk JJ, Cuatrecasas $P$ (1983) Monoclonal antibodies to insulin receptors for insulin and somatomedin C. J Biol Chem 258: 65616566

27. Yamaguchi Y, Flier JS, Yokota A, Benecke H, Backer JM, Moller DE (1991) Functional properties of two naturally occurring isoforms of the human insulin receptor in Chinese hamster ovary cells. Endocrinology 129: 2058-2066

28. Lowry OH, Rosebrough NJ, Farr AL, Randall RJ (1951) Protein measurement with the folin phenol reagent. J Biol Chem 193: 265-275

29. Klein HH, Kowalewski B, Drenckhan M, Neugebauer S, Matthaei S, Kotzke G (1993) A microtiter well assay system to measure insulin-activation of insulin-receptor ki- nase in intact human mononuclear cells: decreased insulin effect in cells from patients with non-insulin-dependent diabetes mellitus. Diabetes 42: 883-890

30. Pilch PF, Czech MP (1979) The subunit structure of the high affinity insulin receptor. J Biol Chem 255: 1722-1731

31. Laemmli UK (1970) Cleavage of structural proteins during the assembly of the head of bacteriophage T4. Nature 227: $680-685$

32. Klein HH, Matthaei S, Drenckhan M, Ries W, Scriba PC (1991) The relationship between insulin binding, insulin activation of receptor tyrosine kinase, and insulin stimulation of glucose uptake in isolated rat adipocytes. Biochem J 274: 787-792

33. Klein HH, Freidenberg GR, Matthaei S, Olefsky JM (1987) Insulin receptor kinase following internalization in isolated rat adipocytes. J Biol Chem 262: 10557-10564

34. Munson PJ, Rodbard D (1980) LIGAND: A versatile computerized approach for characterization of ligand-binding systems. Anal Biochem 107: 220-239

35. Brogden RN, Heel RC (1987) Human insulin. A review of its biological activity, pharmacokinetics and therapeutic use. Drugs 34: 350-371

36. Heinemann L, Richter BR (1993) Clinical pharmacology of human insulin. Diabetes Care 16[Suppl 3]:90-100

37. Lowe WL, Boyd FT, Clarke DW, Raizada MK, Hart C, LeRoizh D (1986) Development of brain insulin receptors: structural and functional studies of insulin receptors from whole brain and primary cell cultures. Endocrinology 119: 25-36

38. Schlüter KJ, Andre J, Enzmann F, Kerp L (1984) Insulin receptor binding in pork brain: different affinities of porcine and human insulin. Horm Metab Res 16: 411-414

39. Gammeltoft S, Staun-Olsen P, Ottensen B, Fahrenkrug J (1984) Insulin receptors in rat brain cortex. Evidence for a receptor subtype in the central nervous system. Peptides 5: 937-944

40. Welinder BS, Linde S, Hansen B, Sonne O (1983) Binding affinity of monoiodinated insulin tracers after reversedphase high-performance liquid chromatography. J Chromatogr 281: 167-177

41. Caro JF, Raju SM, Sinha MK, Goldfine ID, Dohm LN (1988) Heterogeneity of human liver, muscle, and adipose tissue insulin receptor. Biochem Biophys Res Comm 151: 123-129 